\title{
Perbandingan Penggunaan Natrium Perkarbonat, Hidrogen Peroksida, Hipoklorit, dan Xilanase terhadap Sifat Optik Deinked Pulp
}

\author{
Muhammad Ridho dan Edwin K. Sijabat \\ Teknologi Pengolahan Pulp dan Kertas ITSB \\ J1. Ganesha Boulevard, Lot-A 1 CBD Kota Deltamas, Cikarang Pusat, Bekasi
}

Diterima : 12 Agustus 2019, Revisi akhir : 10 Desember 2019, Disetujui terbit : 30 Desember 2019

\section{The Comparison of Sodium Percarbonate, Hydrogen Peroxide, Hypochlorite, and Xylanase on Optical Properties of Deinked Pulp}

\begin{abstract}
The use of raw materials from SWL (sorted white ledger) paper originating from mechanical processes as well as used paper types that contain a lot of ink has a negative impact because it causes no optimal value for the optical properties of deinked pulp. The cause of these problems is the high content of metals and lignin. To overcome this problem, it is necessary to add DTPA (Diethylene Triamine Pentaacetic Acid) as a remover for metals and bleaching agents to remove lignin. The bleaching agents used in this study were sodium percarbonate, hydrogen peroxide, hypochlorite, and xylanase. Variation of bleach dose $(1 \%, 1,5 \%$, and $2 \%)$ and temperature $\left(50^{\circ} \mathrm{C}, 70^{\circ} \mathrm{C}\right.$, and $\left.90^{\circ} \mathrm{C}\right)$ is performed to determine the optimal point. The results showed that the bleaching agents used was able to increase the brightness and whiteness of deinked pulp. The most optimal optical properties values obtained in the bleaching process using $2 \%$ sodium percarbonate at $70^{\circ} \mathrm{C}$, with a brightness of $85.30 \%$ ISO and a whiteness of $112.27 \%$ ISO.
\end{abstract}

Keywords: SWL, waste paper, sodium percarbonate, hydrogen peroxide, hypochlorite, xylanase

\begin{abstract}
Abstrak
Penggunaan bahan baku dari jenis kertas SWL (sorted white ledger) yang berasal dari proses mekanikal dan jenis kertas bekas yang mengandung banyak tinta memiliki dampak negatif karena menyebabkan sifat optik dari deinked pulp yang dihasilkan tidak optimal. Penyebab dari masalah tersebut adalah tingginya kandungan logam dan lignin pada SWL dan kertas bekas. Untuk mengatasi masalah tersebut, pada penelitian ini dilakukan penambahan DTPA (Diethylene Triamine Pentaacetic Acid) sebagai penghilang kandungan logam dan bahan pemutih untuk menghilangkan lignin. Bahan pemutih yang digunakan adalah natrium perkarbonat, hidrogen peroksida, hipoklorit, dan xilanase. Dilakukan variasi dosis $(1 \% ; 1,5 \%$; dan $2 \%)$ dan suhu pemutih $\left(50^{\circ} \mathrm{C}, 70^{\circ} \mathrm{C}\right.$, dan $\left.90^{\circ} \mathrm{C}\right)$ untuk menentukan titik optimal. Hasil penelitian menunjukkan bahwa bahan pemutih yang digunakan mampu meningkatkan derajat cerah dan derajat putih dari deinked pulp. Nilai sifat optik yang paling optimal didapat pada proses pemutihan menggunakan $2 \%$ natrium perkarbonat pada suhu $70^{\circ} \mathrm{C}$, dengan nilai derajat cerah sebesar $85,30 \%$ ISO dan derajat putih sebesar $112,27 \%$ ISO.
\end{abstract}

Kata kunci: SWL, kertas bekas, natrium perkarbonat, hidrogen peroksida, hipoklorit, xilanase 


\section{Pendahuluan}

Pembuatan kertas tulis cetak dari kertas bekas perlu memperhatikan sifat optiknya, khususnya derajat cerah dan derajat putih. Kertas bekas yang digunakan pada penambahan komposisi stock, sebagian terdapat tinta yang masih menempel pada serat. Oleh karena itu, diperlukan beberapa tahap proses untuk menghilangkan tinta dan juga kandungan lignin pada serat serta meningkatkan sifat optik derajat cerah dan derajat putih. Sifat optik derajat cerah dan derajat putih yang rendah disebabkan oleh jenis kertas bekas yang masih mengandung tinta, pewarna, lignin, kandungan logam, dan lainnya. Logam yang terkandung pada stock kertas bekas bersumber dari tinta yang bahannya mengandung logam.

Menurut Bajpai (2014), kertas bekas merupakan bahan baku yang mudah didapat dengan kapasitas yang banyak dan dapat digunakan secara berkelanjutan untuk produksi kertas. Bahan dasar kertas bekas adalah kayu maupun non-kayu yang mengandung selulosa, hemiselulosa, dan lignin. Selain itu juga terdapat bahan kimia kertas. Serat sekunder didefinisikan sebagai material serat yang telah digunakan pada suatu proses manufaktur yang telah didaur-ulang dan digunakan sebagai bahan baku untuk proses manufaktur produk lainnya.

Salah satu alternatif untuk mengatasi kelangkaan dan semakin mahalnya bahan baku kertas dari pulp asli (virgin pulp) adalah pemakaian kembali kertas bekas sebagai bahan baku kertas. Untuk membuat kertas putih tulis cetak dengan memperoleh serat dari jenis kertas bekas SWL (sorted white ledger) yang sebagian merupakan kertas proses mekanis dan mengandung tinta biasanya dilakukan melalui proses deinking yaitu proses penghilangan tinta dari serat dan kemudian dilakukan proses pemutihan. Proses deinking pada dasarnya adalah proses penghilangan tinta. Efektivitas proses deinking tergantung dari bahan baku kertas bekas, jenis kontaminan terutama tinta, tahapan proses yang dilakukan, dan jenis peralatan yang digunakan. Tahapan proses deinking konvensional umumnya meliputi tahap penguraian, pembersihan dan penyaringan, penghilangan tinta, serta tahap pencucian dan pengentalan (Rismijana, Elyani and Cucu, 2006).

Proses deinking terdiri dari beberapa tahapan antara lain; repulping, screening, cleaning, flotation, dan pemutih (Emerson, 2015).
Repulping adalah proses penghancuran kertas menjadi bubur pulp dengan konsistensi rendah 4\%-6\% atau konsistensi tinggi 12\%-15\%, sehingga diperlukan beberapa tahapan proses selanjutnya. Proses screening berfungsi untuk memisahkan dan menyaring partikel-partikel kotoran berdasarkan ukurannya. Proses cleaning berfungsi untuk memisahkan bahan pengotor berdasarkan berat jenis.

Mekanisme flotasi merupakan proses penghilangan partikel-partikel tinta dengan cara membuat gelembung yang kemudian tinta akan menempel pada gelembung tersebut dan terangkat ke udara sehingga mudah untuk dibuang. Penggumpalan tinta ini selanjutnya membentuk partikel yang lebih besar sehingga tinta mudah menempel pada gelembung udara yang naik ke permukaan suspensi (Johnson and Thompson, 1994).

Komponen utama kertas bekas pada umumnya adalah serat dan tinta serta sedikit ion-ion logam, seperti $\mathrm{Fe}, \mathrm{Mn}, \mathrm{Cu}, \mathrm{Ca}, \mathrm{Mg}$, dan lainnya yang bersumber dari kandungan tinta. Keberadaan ion-ion logam dalam pulp dapat menurunkan keefektifan bahan pemutih untuk memutihkan pulp. Sumber utama pencemaran ion-ion logam di dalam sistem pemutihan adalah pulp itu sendiri. Secara umum, tumbuhan memperoleh ion-ion logam dan makanan dari tanah dimana tumbuhan tersebut tumbuh. Sehingga jumlah dan jenis ionion logam yang ada di dalam pulp tergantung dari jenis dan lokasi tumbuh. Sumber pencemaran oleh ion-ion logam dari luar pulp adalah air dan peralatan untuk proses. Kandungan ion-ion logam $\mathrm{Mn}, \mathrm{Cu}$, dan $\mathrm{Fe}$ dapat mempercepat kerusakan selulosa sehingga menurunkan selektivitas pada proses pemutihan (Nakamata, Motoe and Ohi, 2004). Maka dari itu, perlu dilakukan penambahan chelating agent untuk menghilangkan logam.

Lignin dalam pulp dapat diperkirakan menggunakan Bilangan Kappa (Kopra, Lahdeniemi and Dahl, 2019). Lignin merupakan polimer dari unit-unit fenilpropana (Ponnusamy et al., 2019). Berat molekul lignin diperkirakan sangat tinggi, karena proses pemisahan selulosa tidak seutuhnya menyebabkan terikat dalam pulp. Untuk menyatakan sampai tingkat berapa tingginya adalah hal yang tidak mungkin. Karena lignin mengandung sejumlah besar cincin-cincin benzena aktif, lignin yang terdegradasi cepat bereaksi dengan formaldehida, yang telah menyebabkan pengembangan 
komersial terbatas dalam bidang bahan-bahan perekat kayu lapis. Kandungan lignin yang tinggi dalam pulp tidak diinginkan, karena adanya lignin dapat menimbulkan warna coklat pada kertas (Bahri, 2015).

Pemutihan (bleaching) merupakan proses yang bertujuan untuk menghilangkan kandungan lignin (delignifikasi) di dalam pulp atau serat sehingga diperoleh tingkat kecerahan warna yang tinggi dan stabil (Greschik, 2008). Proses pemutihan serat harus menggunakan bahan kimia yang reaktif untuk melarutkan kandungan lignin yang ada di dalam serat agar diperoleh derajat kecerahan yang tinggi (Tutus, 2004). Ada beberapa faktor pada saat proses bleaching yang dominan mempengaruhi antara lain suhu, dosis, dan $\mathrm{pH}$. Adapun bleaching agent yang dapat digunakan yaitu natrium perkarbonat $\left(\mathrm{C}_{2} \mathrm{H}_{6} \mathrm{Na}_{4} \mathrm{O}_{12}\right)$, hipoklorit $\left(\mathrm{ClO}^{-}\right)$, hidrogen peroksida $\left(\mathrm{H}_{2} \mathrm{O}_{2}\right)$ serta xilanase yang merupakan bleaching agent organik dan ramah lingkungan. Natrium perkarbonat adalah senyawa tambahan hidrogen peroksida dan natrium karbonat. Berdasarkan rumus molekuler, natrium perkarbonat murni mengandung 32,5\% hidrogen peroksida dan $67,5 \%$ natrium karbonat (berdasarkan berat), natrium perkarbonat memiliki bentuk berupa bubuk kristal putih (HERA, 2002). Hidrogen peroksida berbentuk cairan tidak berwarna, sedikit lebih kental dari air dan dapat bercampur dengan air dalam berbagai komposisi (Jones, 1999). Hidrogen peroksida bersifat asam yang sangat lemah dan mempunyai kemampuan sifat oksidator yang sangat kuat. Hidrogen peroksida merupakan bahan pemutih yang bisa digunakan untuk proses pemutihan dengan konsep Totally Chlorine Free (TCF) (Liu et al., 2018). Hipoklorit merupakan bahan kimia yang digunakan untuk pemutih produk (Sójka-Ledakowicz et al., 2000). Hipoklorit ini terdiri dari klor dan oksigen dengan rumus kimia $\mathrm{ClO}^{-}$. Senyawa ini merupakan klorin aktif yang paling aktif dan banyak digunakan untuk pemutihan, secara kimiawi hipoklorit bersifat kurang stabil. Penggunaan enzim dalam pemutihan pulp dikenal sebagai biobleaching. Penggunaan xilanase menghasilkan pulp dengan kecerahan tinggi dan menghemat bahan kimia pemutihan (Bajpai, 2018).

Penelitian ini dilakukan untuk mempelajari perbandingan penggunaan aditif natrium perkarbonat, hidrogen peroksida, hipoklorit, dan xilanase terhadap sifat optik dari deinked pulp.

\section{Bahan dan Metode}

Bahan penelitian yang digunakan adalah kertas SWL (Sorted White Ledger), kertas NCR (No-Carbon Required), kertas avalan CVT (Converting), $\mathrm{NaOH}$, dispersan, surfaktan, natrium perkarbonat, hidrogen peroksida, hipoklorit, xilanase, DTPA (Diethylene Triamine Pentaacetic Acid), fresh water, $\mathrm{HCl}$ (asam klorida), KCN (kalium sianida), $\mathrm{NH}_{2} \mathrm{OH}$. $\mathrm{HCl}$ (hidroksilamin hidroklorida), indikator magnesium. EDTA 0,005 N, KOH (kalium hidroksida) $8 \mathrm{~N}$, dan calcium indikator. Variabel bebas pada penelitian ini yaitu bahan pemutih, suhu $\left(50^{\circ} \mathrm{C}, 70^{\circ} \mathrm{C}\right.$, dan $\left.90^{\circ} \mathrm{C}\right)$, dan variasi dosis bahan pemutih $(1 \%$; $1,5 \%$; dan $2 \%)$ terhadap pulp sedangkan variabel terikat pada penelitian ini yaitu derajat cerah dan derajat putih. Variabel kontrol penelitian ini yaitu waktu reaksi, tekanan udara (bar), dosis surfaktan, dosis dispersan, dosis $\mathrm{NaOH}$, komposisi stock, dosis DTPA, $\mathrm{pH}$, dan bilangan Kappa.

Pada pemeriksaan kadar logam terdapat sampel blank stock, sampel stock I, sampel stock II, sampel stock III dan sampel stock IV. Setiap sampel stock merupakan perlakukan yang berbeda untuk dilakukan pemeriksaan kandungan logam. Sampel stock blank adalah parameter awal sebagai acuan terhadap hasil uji sampel lainnya. Sampel stock I merupakan sampel yang diuji kandungan logamnya untuk proses pemutihan menggunakannatriumperkarbonat, SampelstockII menggunakan hidrogen peroksida, Sampel stock III menggunakan hipoklorit dan sampel stock IV menggunakan xilanase.

Penelitian dilakukan dengan pembuatan dan pengujian handsheet. Pada percobaan ini, dilakukan proses flotasi untuk menghilangkan tinta. Adapun proses pemutihan yang merupakan tujuan utama dalam penelitian ini dengan memvariasikan dosis, suhu, dan bahan kimia pemutih sebagai variable control penelitian. Setelah proses deinking dan pemutihan dilakukan, stock dibuat handsheet, kemudian diuji sifat optik dengan parameter pengujian seperti diagram alir percobaan pada Gambar 1.

\section{Hasil dan Pembahasan}

\section{pH Stock}

Derajat keasaman $(\mathrm{pH})$ pada proses pemutihan harus dijaga pada kondisi alkali agar bahan 


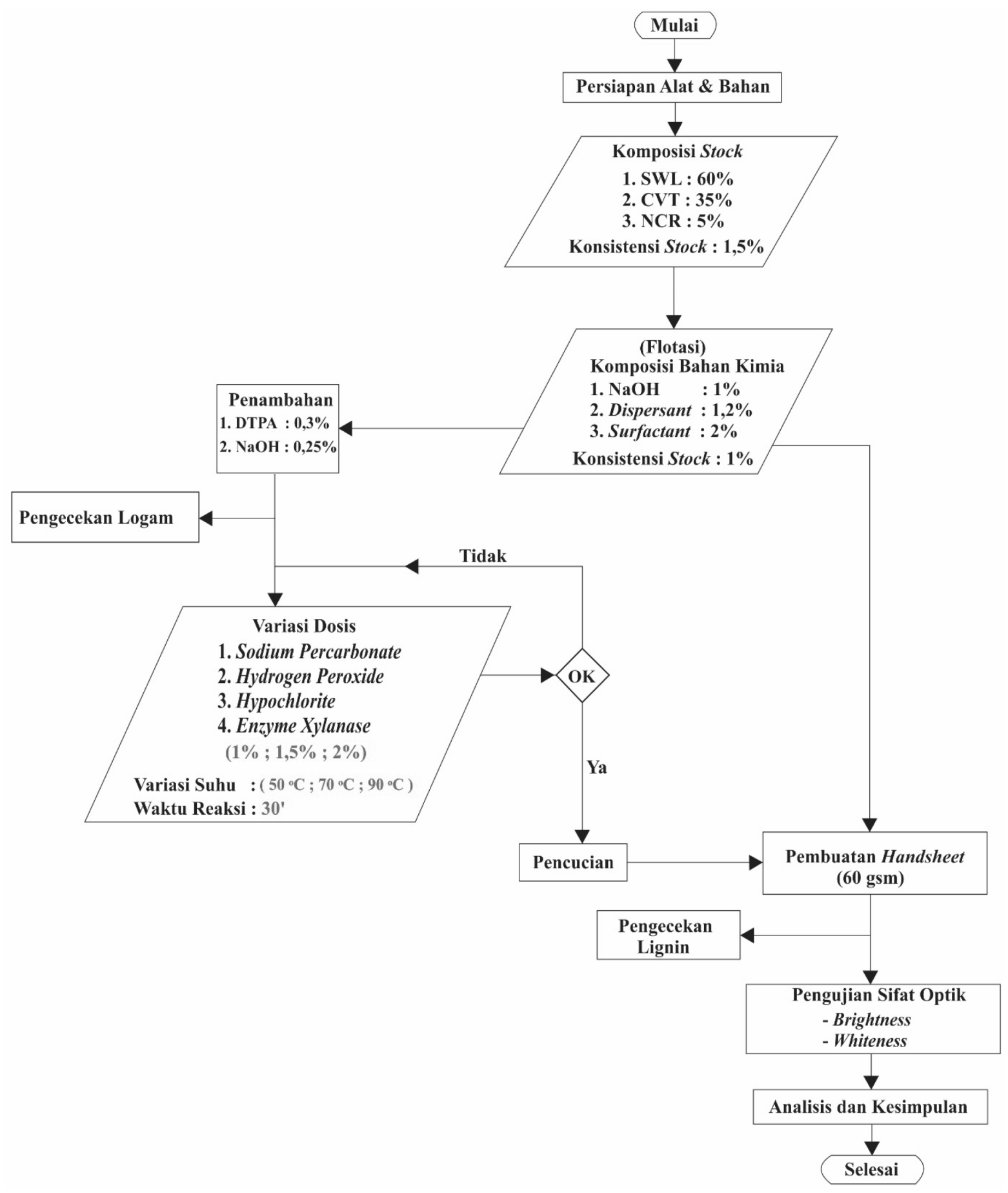

Gambar 1. Diagram Alir Percobaan

pemutih dapat bereaksi dengan lignin dan serat. Tabel 1 menunjukkan bahwa kondisi awal $\mathrm{pH}$ stock setelah dilakukan repulping menunjukkan sudah dalam kondisi basa dengan nilai 7,52 - 7,65. Namun, nilai $\mathrm{pH}$ pada proses flotasi adalah 8,61 - 8,76 karena ditambahkan $\mathrm{NaOH}$. Adapun nilai $\mathrm{pH}$ setelah dilakukan pencucian adalah $7,62-7,73$.
Dari hasil percobaan yang telah dilakukan, didapatkan nilai $\mathrm{pH}$ proses pemutihan seperti pada Tabel 2, Tabel 3 dan Tabel 4.

Pemeriksaan nilai $\mathrm{pH}$ pada saat pemutihan merupakan pengukuran reaksi bahan kimia pemutih terhadap serat. Hasil pemeriksaan $\mathrm{pH}$ sebelum dan setelah ditambahkan $\mathrm{NaOH}$ terlihat pada Tabel 2, Tabel 3 dan Tabel 4. Pemeriksaan 
Tabel 1. Nilai pH sebelum Pemutihan

\begin{tabular}{lccc}
\hline $\begin{array}{l}\text { Proses } \\
\text { Pembuatan } \\
\text { Stock Pulp }\end{array}$ & $\begin{array}{c}\text { pH Setelah } \\
\text { Repulping }\end{array}$ & $\begin{array}{c}\mathrm{pH} \text { Flotasi } \\
(+\mathrm{NaOH} \\
1 \%)\end{array}$ & $\begin{array}{c}\mathrm{pH} \mathrm{Stock} \\
\text { Setelah } \\
\text { Pencucian dari } \\
\text { Proses Flotasi }\end{array}$ \\
\hline Proses 1 & 7,54 & 8,68 & 7,62 \\
Proses 2 & 7,62 & 8,75 & 7,70 \\
Proses 3 & 7,52 & 8,76 & 7,72 \\
Proses 4 & 7,63 & 8,63 & 7,64 \\
Proses 5 & 7,60 & 8,67 & 7,66 \\
Proses 6 & 7,58 & 8,74 & 7,69 \\
Proses 7 & 7,65 & 8,61 & 7,73 \\
Proses 8 & 7,58 & 8,65 & 7,63 \\
\hline
\end{tabular}

Tabel 2. Nilai pH Pemutih pada Dosis 1\%

\begin{tabular}{lccc}
\hline $\begin{array}{l}\text { Bahan } \\
\text { pemutih }\end{array}$ & Suhu $50^{\circ} \mathrm{C}$ & Suhu $70^{\circ} \mathrm{C}$ & Suhu $90^{\circ} \mathrm{C}$ \\
\hline $\begin{array}{l}\text { Natrium } \\
\text { perkarbonat }\end{array}$ & 9,3 & 9,2 & 9,4 \\
$\begin{array}{l}\text { Hipoklorit } \\
\text { Hidrogen } \\
\text { peroksida }\end{array}$ & 9,2 & 9,3 & 9,3 \\
Xilanase & 9,4 & 9,3 & 9,2 \\
\hline
\end{tabular}

Tabel 3. Nilai $\mathrm{pH}$ Pemutih pada Dosis $1,5 \%$

\begin{tabular}{lccc}
\hline $\begin{array}{l}\text { Bahan } \\
\text { pemutih }\end{array}$ & Suhu $50^{\circ} \mathrm{C}$ & Suhu $70^{\circ} \mathrm{C}$ & Suhu $90^{\circ} \mathrm{C}$ \\
\hline $\begin{array}{l}\text { Natrium } \\
\text { perkarbonat }\end{array}$ & 9,5 & 9,5 & 9,4 \\
$\begin{array}{l}\text { Hipoklorit } \\
\begin{array}{l}\text { Hidrogen } \\
\text { peroksida }\end{array}\end{array}$ & 9,3 & 9,2 & 9,3 \\
Xilanase & 9,4 & 9,4 & 9,5 \\
\hline
\end{tabular}

Tabel 4. Nilai $\mathrm{pH}$ Pemutih pada Dosis 2\%

\begin{tabular}{lccc}
\hline $\begin{array}{l}\text { Bahan } \\
\text { pemutih }\end{array}$ & Suhu $50^{\circ} \mathrm{C}$ & Suhu $70^{\circ} \mathrm{C}$ & Suhu $90^{\circ} \mathrm{C}$ \\
\hline $\begin{array}{l}\text { Natrium } \\
\text { perkarbonat }\end{array}$ & 9,5 & 9,3 & 9,4 \\
$\begin{array}{l}\text { Hipoklorit } \\
\begin{array}{l}\text { Hidrogen } \\
\text { peroksida }\end{array}\end{array}$ & 9,3 & 9,3 & 9,3 \\
Xilanase & 9,4 & 9,3 & 9,4 \\
\hline
\end{tabular}

tersebut bertujuan untuk menjaga kestabilan proses pemutihan, karena proses pemutihan efektif bekerja pada $\mathrm{pH} 8,5$ - 11. Jika $\mathrm{pH}$ pada suasana asam maka bahan pemutih tidak efektif. Pada penggunaan bahan pemutihan dengan dosis $1 \%$ di suhu $50^{\circ} \mathrm{C}, 70^{\circ} \mathrm{C}$, dan $90^{\circ} \mathrm{C}$ nilai $\mathrm{pH}$-nya adalah 9,2-9,4. Sedangkan dosis pemutih 1,5\% di suhu $50^{\circ} \mathrm{C}, 70^{\circ} \mathrm{C}$, dan $90^{\circ} \mathrm{C}$ nilai $\mathrm{pH}$-nya adalah 9,2-9,5. Adapun penggunaan bahan pemutih dengan dosis $2 \%$ di suhu $50^{\circ} \mathrm{C}, 70^{\circ} \mathrm{C}$, dan $90^{\circ} \mathrm{C}$ nilai $\mathrm{pH}$-nya adalah 9,3-9,5.

\section{Pengujian Logam pada Stock}

Hasil pengujian kadar logam $\mathrm{Ca}^{++}$dan $\mathrm{Mg}^{++}$ dengan menggunakan proses titrasi dapat dilihat pada Gambar 2 dan Gambar 3. Terlihat bahwa

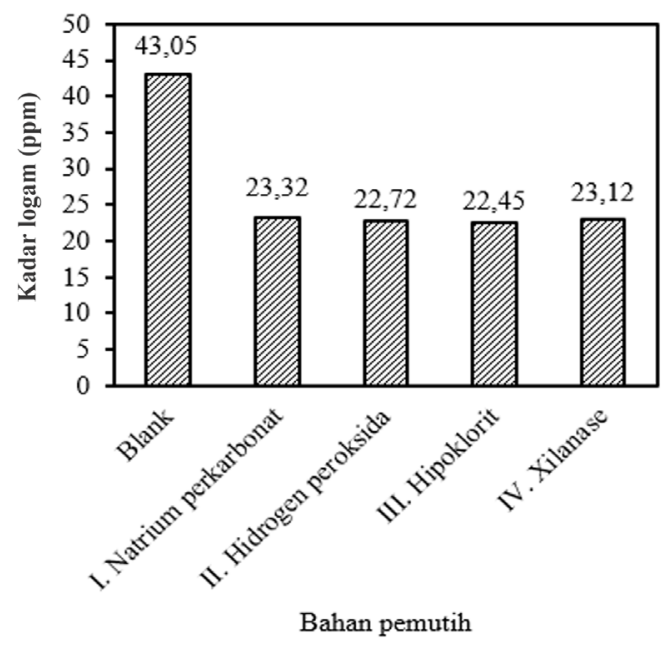

Gambar 2. Nilai Logam $\mathrm{Ca}^{++}$

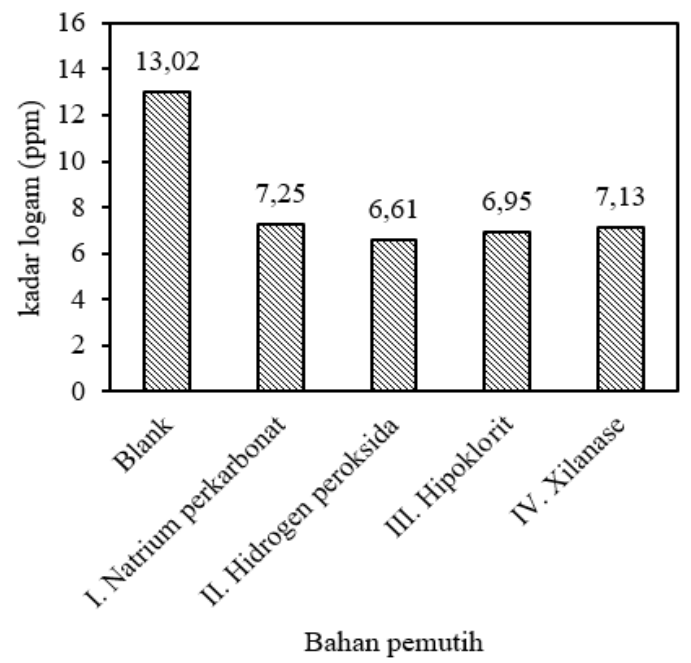

Gambar 3. Nilai Logam $\mathrm{Mg}^{++}$ 
kandungan logam $\mathrm{Ca}^{++}$lebih tinggi dari $\mathrm{Mg}^{++}$. Nilai logam $\mathrm{Ca}^{++}$yang didapat dari hasil pengujian terhadap sampel stock adalah 22,45-43,05 ppm dan nilai logam $\mathrm{Mg}^{++}$adalah 6,61-13,02 ppm. Dari pemeriksaan kadar logam $\mathrm{Ca}^{++}$dan $\mathrm{Mg}^{++}$ dengan DTPA didapatkan rasio antara sampel blank dengan sampel I, II, III, dan IV.

Dari data tersebut menunjukkan bahwa kandungan logam sampel stock I, II, III, dan IV lebih rendah dari kandungan logam sampel stock blank karena ke-empat sampel tersebut ditambahkan bahan kimia penghilang logam dengan dosis $0,3 \%$. Hasil tersebut mengindikasikan bahwa penambahan DTPA (Diethylene Triamine Pentaacetic Acid) dapat menurunkan kandungan logam dalam stok.

\section{Bilangan Kappa}

Percobaan proses pemutihan pulp dengan menggunakan bahan pemutih perlu diketahui kadar lignin atau bilangan Kappa. Pengujian bilangan Kappa disajikan pada Gambar 4, Gambar 5, dan Gambar 6.

Penggunaan bahan pemutih dapat menurunkan kadar lignin sehingga dapat meningkatkan kecerahan pemutihan pulp. Gambar 4 menunjukkan pengujian bilangan Kappa dari sampel stock dengan menggunakan bahan pemutih pada suhu $50^{\circ} \mathrm{C}$. Diketahui nilai kadar lignin dengan dosis $0 \%$ adalah 15,06 yang merupakan acuan dari sampel pengujian kadar lignin lainnya.

Sampel dengan dosis 0\% tersebut merupakan bahan pengujian kadar lignin yang tidak terdapat bahan pemutih sehingga nilai kadar ligninnya lebih rendah dari sampel pemutih yang lain.

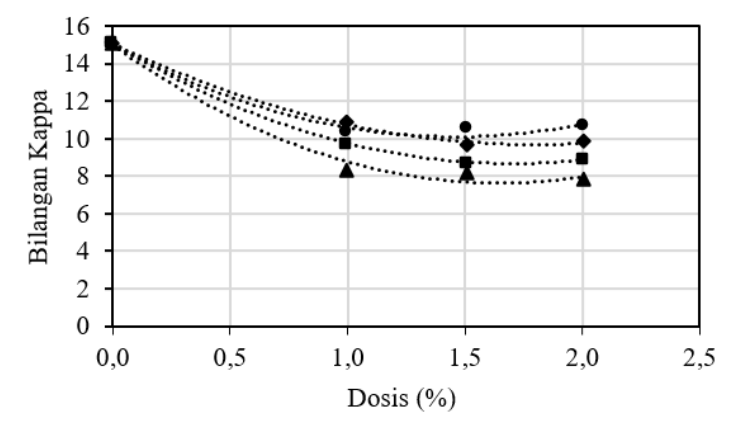

Gambar 4. Pengaruh dosis terhadap Bilangan Kappa pada suhu $50^{\circ} \mathrm{C}(\boldsymbol{\Delta}$ : Natrium perkarbonat, m: Hidrogen peroksida, $\bullet$ : Hipoklorit, $\bullet$ : Xilanase)
Pemeriksaan bilangan Kappa dari sampel yang menggunakan bahan pemutih didapatkan yang paling optimal adalah natrium perkarbonat dengan nilai 7,79 pada dosis $2 \%$. Sedangkan nilai paling optimal dari pembanding bilangan Kappa yang terdapat bahan pemutih lainnya yaitu hidrogen peroksida sebesar 8,76 pada dosis $1,5 \%$, hipoklorit sebesar 9.76 pada dosis $1,5 \%$, dan xilanase sebesar 10,32 pada dosis $1 \%$.

Gambar 5 merupakan pengujian bilangan Kappa dari sampel stock dengan menggunakan bahan pemutih pada suhu $70^{\circ} \mathrm{C}$. Pemeriksaan bilangan Kappa dari sampel yang menggunakan bahan pemutih didapatkan yang paling optimal adalah natrium perkarbonat dengan nilai 6,23 pada dosis $2 \%$. Sedangkan nilai paling optimal dari pembanding bilangan Kappa yang terdapat bahan pemutih lainnya yaitu hidrogen peroksida sebesar 8,13 pada dosis $2 \%$, hipoklorit sebesar 9.23 pada dosis $2 \%$, dan xilanase sebesar 11,77 pada dosis $1 \%$.

Pada Gambar 6 dapat dilihat bilangan Kappa dari sampel stock dengan menggunakan bahan

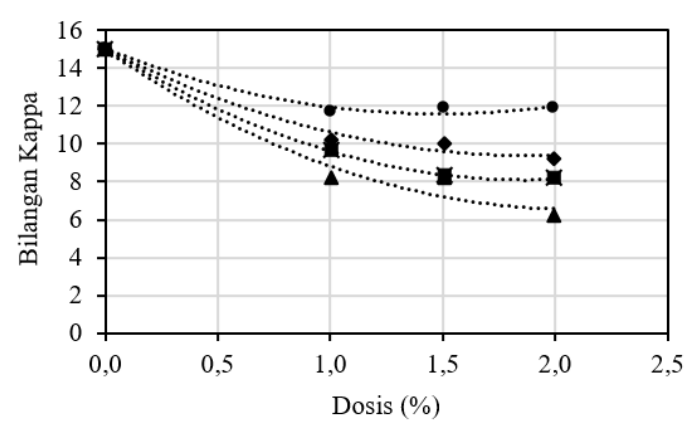

Gambar 5. Pengaruh Dosis terhadap Bilangan Kappa pada Suhu $70^{\circ} \mathrm{C}(\boldsymbol{\Delta}$ : Natrium perkarbonat, п: Hidrogen peroksida, $\bullet$ : Hipoklorit, $\bullet$ : Xilanase)

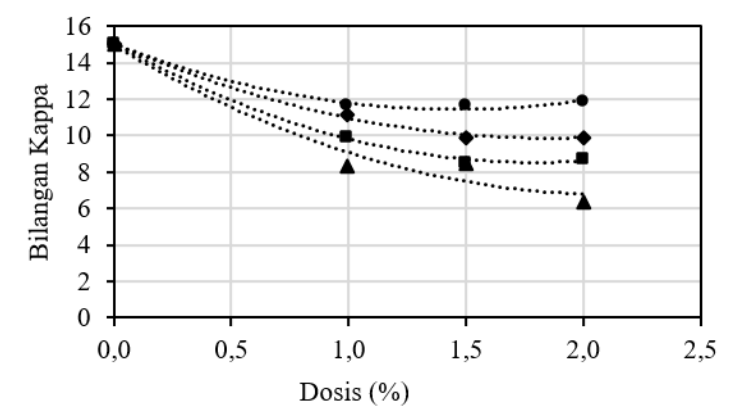

Gambar 6. Pengaruh Dosis terhadap Bilangan Kappa pada Suhu $90^{\circ} \mathrm{C}$ ( $\boldsymbol{\Delta}$ : Natrium perkarbonat, m: Hidrogen peroksida, $\bullet$ : Hipoklorit, $\bullet$ : Xilanase) 
pemutih pada suhu $90^{\circ} \mathrm{C}$. Pemeriksaan bilangan Kappa dari sampel yang menggunakan bahan pemutih didapatkan yang paling optimal adalah natrium perkarbonat dengan nilai 6,42 pada dosis $2 \%$ sedangkan nilai paling optimal dari pembanding bilangan Kappa yang terdapat bahan pemutih lainnya yaitu hidrogen peroksida sebesar 8,53 pada dosis 1,5\%, hipoklorit sebesar 9,92 pada dosis 1,5\%, dan xilanase sebesar 11,62 pada dosis $1 \%$.

\section{Hasil Pengujian Sifat Optik}

Pengujian yang dilakukan terhadap sifat optik ini memiliki nilai awal cukup tinggi seperti nilai derajat cerah yaitu sekitar $80,45 \%$ ISO. Akan tetapi, pembuatan kertas tulis cetak di setiap industri kertas yang menggunakan pulp dari deinking nilai tersebut terlalu rendah. Nilai derajat cerah pulp deinking yang ditarget ratarata di atas $84 \%$ ISO, serta menyesuaikan dengan permintaan pelanggan.

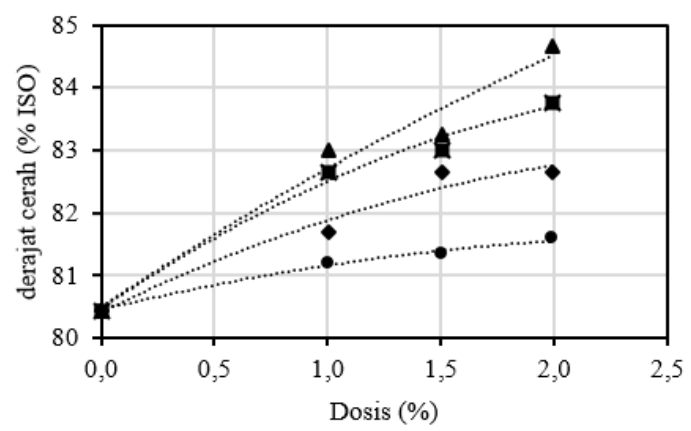

Gambar 7. Nilai Derajat Cerah pada Suhu $50^{\circ} \mathrm{C}$ $(\boldsymbol{\Lambda}$ : Natrium perkarbonat, $\mathbf{\square}$ : Hidrogen peroksida, $\diamond$ : Hipoklorit, $\bullet$ : Xilanase)

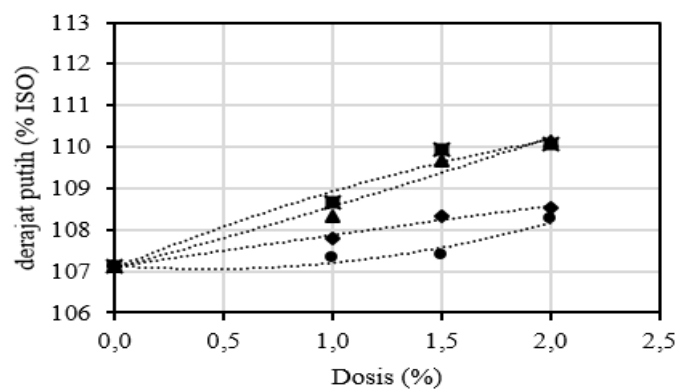

Gambar 8. Nilai Derajat Putih pada Suhu $50^{\circ} \mathrm{C}$ $(\boldsymbol{\Delta}$ : Natrium perkarbonat, $\mathbf{\square}$ : Hidrogen peroksida, $\diamond$ : Hipoklorit, $\bullet$ : Xilanase)
Pengujian terhadap nilai sifat optik berupa derajat cerah dan derajat putih yang disajikan pada Gambar 7 sampai dengan Gambar 12. Nilai awal derajat cerah dan derajat putih sampel masing-masing $80,45 \%$ ISO dan $107,12 \%$ ISO.

Nilai derajat cerah yang optimal pada pemutihan dengan suhu $50^{\circ} \mathrm{C}($ Gambar 7) adalah pada natrium perkarbonat dengan nilai $84,67 \%$ ISO dengan dosis $2 \%$. Sedangkan nilai tertinggi untuk bahan pemutih yang lain yaitu hidrogen peroksida sebesar $83,77 \%$ ISO dengan dosis $2 \%$, hipoklorit sebesar $82,67 \%$ ISO dengan dosis $2 \%$, dan xilanase sebesar $81,57 \%$ ISO dengan dosis 2\%. Gambar 8 menunjukkan derajat putih pada proses pemutihan suhu $50^{\circ} \mathrm{C}$ yang optimal yaitu natrium perkarbonat sebesar $110,12 \%$ ISO dengan dosis $2 \%$, hidrogen peroksida sebesar $110,04 \%$ ISO dengan dosis $2 \%$, hipoklorit sebesar $108,54 \%$ ISO dengan dosis $2 \%$, dan xilanase sebesar $107,23 \%$ ISO dengan dosis $2 \%$. Sehingga penggunaan natrium perkarbonat lebih efektif dan dapat meningkatkan nilai derajat cerah dan derajat putih lebih tinggi dari bahan kimia pemutih yang lain.

Nilai derajat cerah yang optimal pada pemutihan dengan suhu $70^{\circ} \mathrm{C}$ adalah pada natrium perkarbonat dengan nilai 85,3\% ISO dengan dosis 2\% (Gambar 9). Sedangkan nilai tertinggi untuk bahan pemutih yang lain yaitu hidrogen peroksida sebesar $84,01 \%$ ISO dengan dosis $2 \%$, hipoklorit sebesar $83,11 \%$ ISO dengan dosis $2 \%$, dan xilanase sebesar $80,79 \%$ ISO dengan dosis 2\%. Gambar 10 menunjukkan derajat putih pada proses pemutihan suhu $70^{\circ} \mathrm{C}$ yang optimal yaitu natrium perkarbonat sebesar $112,27 \%$ ISO

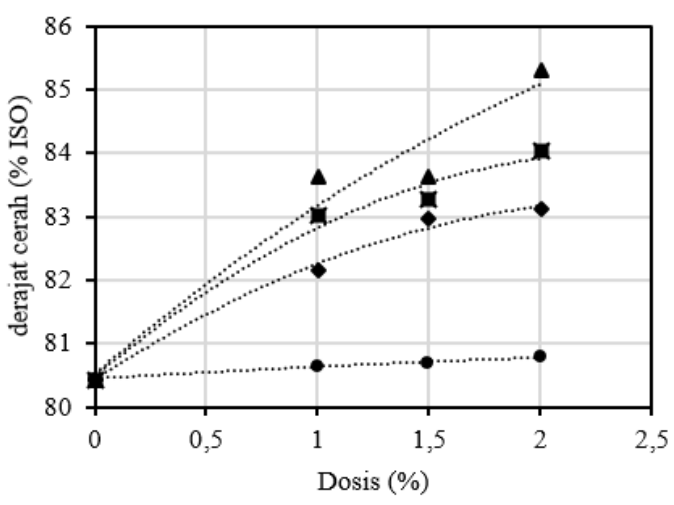

Gambar 9. Nilai Derajat Cerah pada Suhu $70^{\circ} \mathrm{C}$ ( $\boldsymbol{\Delta}$ : Natrium perkarbonat, $\mathbf{m}$ : Hidrogen peroksida, $\diamond$ : Hipoklorit, $\bullet$ : Xilanase) 


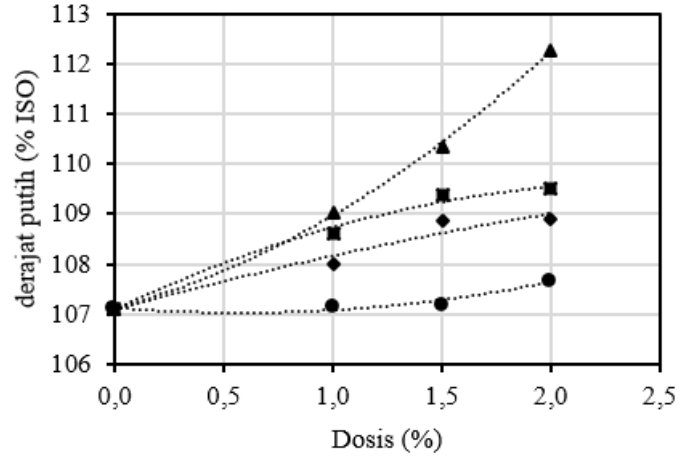

Gambar 10. Nilai Derajat Putih pada Suhu $70^{\circ} \mathrm{C}$ ( $\mathbf{\Delta}$ : Natrium perkarbonat, $\mathbf{\square}$ : Hidrogen peroksida, $\checkmark$ : Hipoklorit, $\bullet$ : Xilanase)

dengan dosis $2 \%$, hidrogen peroksida sebesar $109,49 \%$ ISO dengan dosis 2\%, hipoklorit sebesar 108,92\% ISO dengan dosis $2 \%$, dan xilanase sebesar $107,68 \%$ ISO dengan dosis $2 \%$. Sehingga penggunaan natrium perkarbonat lebih efektif untuk meningkatkan nilai brightness (derajat cerah) dan whiteness (derajat putih) lebih tinggi dari bahan kimia pemutih yang lain.

Nilai derajat cerah yang optimal pada pemutihan dengan suhu $70^{\circ} \mathrm{C}$ adalah pada natrium perkarbonat dengan nilai $85,11 \%$ ISO dengan dosis 2\% (Gambar 11). Sedangkan nilai tertinggi dari pembanding bahan pemutih yang lain yaitu hidrogen peroksida sebesar $83,56 \%$ ISO dengan dosis $2 \%$, hipoklorit sebesar $82,83 \%$ ISO dengan dosis $2 \%$, dan xilanase sebesar $80,73 \%$ ISO dengan dosis $2 \%$. Gambar 12 menunjukkan derajat putih pada proses pemutihan suhu $70^{\circ} \mathrm{C}$

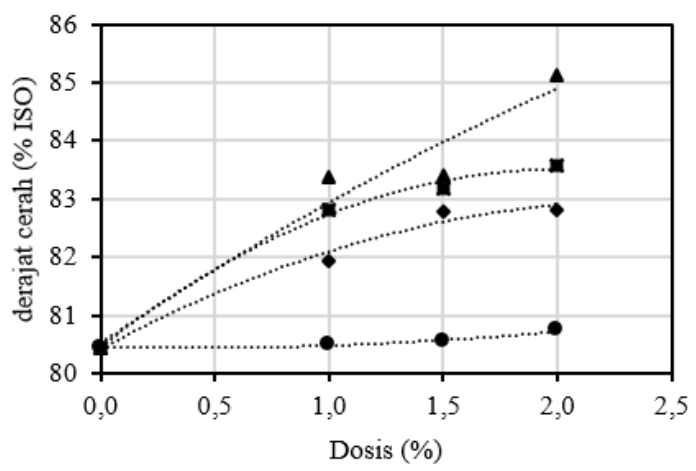

Gambar 11. Nilai Derajat Cerah pada Suhu $90^{\circ} \mathrm{C}$ ( $\boldsymbol{\Delta}$ : Natrium perkarbonat, $\mathbf{\square}$ : Hidrogen peroksida, $\diamond$ : Hipoklorit, $\bullet$ : Xilanase) yang optimal yaitu natrium perkarbonat sebesar $111,41 \%$ ISO dengan dosis $2 \%$, hidrogen peroksida sebesar $109,23 \%$ ISO dengan dosis $1,5 \%$, hipoklorit sebesar 108,72\% ISO dengan dosis $2 \%$, dan xilanase sebesar $107,56 \%$ ISO dengan dosis $2 \%$ sehingga penggunaan natrium perkarbonat lebih efektif untuk meningkatkan nilai derajat cerah dan derajat putih lebih tinggi dari bahan kimia pemutih yang lain.

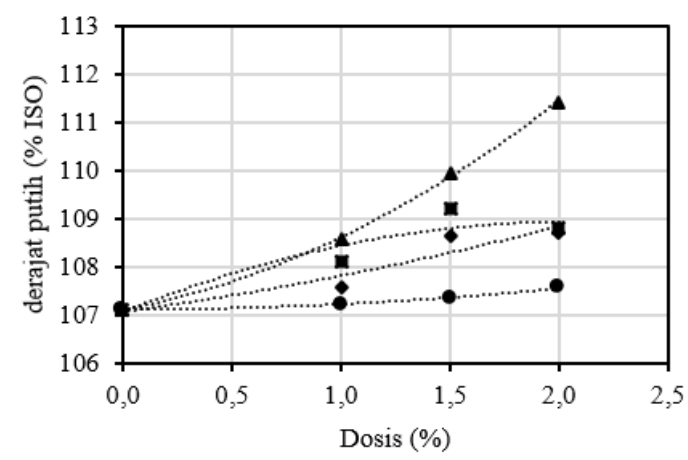

Gambar 12. Nilai Derajat Putih pada Suhu $90^{\circ} \mathrm{C}$ ( $\boldsymbol{\Delta}$ : Natrium perkarbonat, $\mathbf{m}$ : Hidrogen peroksida, $\bullet$ : Hipoklorit, $\bullet$ : Xilanase)

\section{Kesimpulan}

Bahan pemutih natrium perkarbonat, hidrogen peroksida, hipoklorit, dan xilanase mampu meningkatkan sifat optik kertas yaitu derajat cerah dan derajat putih. Nilai derajat cerah dan derajat putih terbaik diperoleh dengan menggunakan natrium perkarbonat dengan dosis $2 \%$ pada suhu $70^{\circ} \mathrm{C}$ dengan nilai derajat cerah yang didapat adalah $85,30 \%$ ISO dan nilai derajat putih adalah $112,27 \%$ ISO. Penambahan DTPA (Diethylene Triamine Pentaacetic Acid) dengan dosis $0,3 \%$ mampu menurunkan kadar logam yang terkandung dalam stock. Nilai rasio yang tertinggi dari sampel stock adalah $\mathrm{Ca}^{++}$sebesar 20,60 ppm dan $\mathrm{Mg}^{++}$sebesar 6,41 ppm. Nilai tersebut mengindikasikan bahwa DTPA efektif digunakan sebagai penghilang kadar logam. Penggunaan bahan pemutih natrium perkarbonat, hidrogen peroksida, hipoklorit, dan xilanase mampu menurunkan kadar lignin atau bilangan Kappa. Bahan pemutih terbaik yang mampu menurunkan bilangan Kappa adalah natrium perkarbonat dengan nilai sebesar 6,23 dan pada nilai blank sebesar 15,06 dengan dosis $2 \%$ pada suhu $70^{\circ} \mathrm{C}$. 


\section{Daftar Pustaka}

Bahri, S. (2015) 'Pembuatan Pulp dari Batang Pisang', Jurnal Teknologi Kimia Unimal, 4(2), p. 36. doi: 10.29103/jtku.v4i2.72.

Bajpai, P. (2014) Recycling and Deinking of Recovered Paper, Recycling and Deinking of Recovered Paper. London: Elsevier Inc. doi: 10.1016/C2013-0-00556-7.

Bajpai, P. (2018) 'Biobleaching', in Biotechnology for Pulp and Paper Processing. Singapore: Springer Singapore, pp. 159-213. doi: 10.1007/978-981-10-7853-8 10.

Emerson (2015) pH Measurement in Deinking Mills (Secondary Fiber), Application Note. Available at: https:// www.pulpandpaperonline.com/doc/phmeasurement-in-deinking-mills-secondaryfiber-0001.

Greschik, T. (2008) 'Treatment of Pulp'. United States Patent Application.

HERA (2002) Human \& Environmental Risk Assessment on ingredients of European household cleaning products: Sodium percarbonate (CAS No. 15630-89-4).

Johnson, D. A. and Thompson, E. V. (1994) 'Fiber/Toner Detachment Studies: Repulping and Flotation of Laser Printed Paper, Part I', in Pulping Conference Proceedings.

Jones, C. W. (1999) Applications of Hydrogen Peroxide and Derivatives. Cambridge: Royal Society of Chemistry (RSC Clean Technology Monographs). doi: 10.1039/9781847550132.

Kopra, R., Lahdeniemi, A. and Dahl, O. (2019) 'Evaluating the lignin content in the fibreline of a birch kraft pulp mill with a TDS sensor', Appita Journal, 72(3), pp. 150-162.
Liu, Y., Ge, S., Li, Y., Li, B. and Li, H. (2018) 'Oxalate formation during hydrogen peroxide-reinforced oxygen delignification', Journal of Industrial and Engineering Chemistry, 58, pp. 45-50. doi: 10.1016/j. jiec.2017.09.005.

Nakamata, K., Motoe, Y. and Ohi, H. (2004) 'Evaluation of chloroform formed in process of kraft pulp bleaching mill using chlorine dioxide', Journal of Wood Science, 50, pp. 242-247.

Ponnusamy, V. K., Nguyen, D. D., Dharmaraja, J., Shobana, S., Banu, J. R., Saratale, R. G., Chang, S. W. and Kumar, G. (2019) 'A review on lignin structure, pretreatments, fermentation reactions and biorefinery potential', Bioresource Technology, 271, pp. 462-472. doi: 10.1016/j. biortech.2018.09.070.

Rismijana, J., Elyani, N. and Cucu, C. (2006) 'Efektivitas Biodeinking pada Pengolahan Kertas Bekas Campuran', Berita Selulosa, 41(1), pp. 14-20.

Sójka-Ledakowicz, J., Gajdzicki, B., Lewartowska, J. and Machnowski, W. (2000) 'Procesy enzymatyczne jako alternatywa dla tradycyjnych technologii wykończalniczych', Przegląd Włókienniczy, 5, pp. 28-31.

Tutus, A. (2004) 'Bleaching of Rice Straw Pulps with Hydrogen Peroxide', Pakistan Journal of Biological Sciences, 7(8), pp. 1327-1329. doi: 10.3923/pjbs.2004.1327.1329. 
Lurnal Selulosa, Vol. 9, No. 2, Desember 2019: 97 - 106

- Halaman ini sengaja dikosongkan - 